\title{
НАШ ВНЕСОК У ТРАНСФОРМАЦІЙНІ ПРОЦЕСИ: ЯКИМ ВІН Є І ЩО ПОТРІБНО ДЛЯ ЙОГО ЗБІЛЬШЕННЯ
}

Наукова доповідь на загальних зборах НАПН України 17 грудня 2019 р.

https://doi.org/10.37472/2707-305X-2019-1-1-1-2

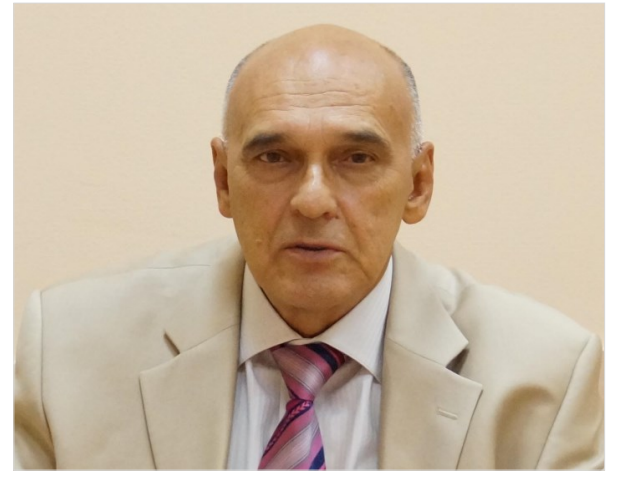

\section{СЛЮСАРЕВСЬКИЙ}

\section{Микола Миколайович}

кандидат психологічних наук, член-кореспондент НАПН України, директор Інституту соціальної та політичної психології Національної академії педагогічних наук України, м. Київ, Україна
Анотація. Схарактеризовано основні напрями супроводу українськими соціальними психологами трансформаційних процесів у суспільстві та освіті: 1) відстеження тенденцій динаміки суспільної свідомості за допомогою всеукраїнських репрезентативних опитувань; 2) розроблення практично зорієнтованих теорій, моделей концепцій, що складають теоретико-методологічний фундамент як дослідження, так і супроводження суспільних змін; 3) донесення отриманих даних і наукових розробок до споживача, науковометодична допомога органам державної влади. Водночас констатовано, що можливості психологічного супроводу трансформацій них процесів в освіті, а тим паче в суспільстві загалом, наразі обмежені як недостатньою державною підтримкою розвитку психологічної науки, так і відсутністю дієвих механізмів упровадження наявних розробок і рекомендачій. Обгрунтовано необхідність затвердження на урядовому рівні Державної цільової програми розвитку психологічної науки в Україні. Порушено надзвичайно гостру для країни, що фрактично перебуває в стані війни, проблему підготовки психологічних кадрів. Для ії актуалізації проведено порівняльний аналіз стану підготовки психологів в Україні і США. Зроблено висновок про потребу збільшення обсягів і водночас більш раціональної реалізачії державного замовлення на підготовку вітчизняних психологічних кадрів, що передбачає його розміщення у провідних університетах та наукових установах психологічного профілю.

Ключові слова: суспільство; освіта, психологічний супровід; Державна програма розвитку психологічної науки; психологічні кадри; державне замовлення на підготовку психологів.

Передусім хочу засвідчити підтримку положень доповіді С.Д. Максименка - академіка-секретаря Відділення психології, вікової фізіології та дефектології, до якого належить і наш Інститут соціальної та політичної психології НАПН України.

У доповіді почасти йшлося про нашу роботу в означеному напрямку. Але було б, мабуть, нелогічно, якби директор Інституту, виступаючи на загальних зборах НАПН України, не доповів бодай у найкоротшому форматі про внесок колективу у вирішення питання, яке обговорюється, не схарактеризував цей внесок у цілому. Тому мій виступ складатиметься з двох частин: констатувальної, що конкретизує окремі положення доповіді, і проблемно-постановочної, яка теж певною мірою доповнює доповідь.

Отже, якщо говорити про внесок Інституту у вирішення питань психологічного супроводу трансформаційних процесів у суспільстві та освіті, то він полягає, по-перше, у відстеженні 
стану і динаміки суспільної свідомості, особливостей реагування громадської думки на реформи, що здійснюються або лише проголошуються i, залишаючись на папері, породжують у суспільстві зрозуміле невдоволення. Під відстеженням стану і динаміки суспільної свідомості, звичайно, розумію не умоглядні висновки, а дослідження на репрезентативних вибірках.

Не маючи, на жаль, жодних цільових коштів на проведення масових опитувань, Інститут усе ж вишуковує можливості і з року в рік проводить їх у рамках унікальних моніторингових циклів, що дають цілісне уявлення про стан справ у суспільстві та освіті. У систематизованому вигляді дані цих моніторингів за останні п'ять років відображено і прокоментовано в довідковому виданні «Соціальна ситуація в Україні: особливості відображення трансформаційних процесів у громадській думці» (2014-2018рр.), яке ми підготували за однією з планових тем.

По-друге, внесок Інституту полягає у створенні теоретико-методологічного фундаменту як дослідження, так і супроводження суспільних змін. В Інституті розроблено низку практично зорієнтованих теорій, моделей і концепцій, що охоплюють такі питання:

- соціальна напруженість і протестний потенціал суспільства;

- налагодження в суспільстві соціальних діалогів;

- процеси зовнішньої і внутрішньої міграції;

- розвиток територіальних спільнот;

- адаптація спільноти до суспільних змін, зокрема пов'язаних з переживанням травматичного досвіду війни;

- громадська думка щодо стану і розвитку освіти;

- особистісне життєконструювання і керування ризиками (у т.ч. в ситуації взаємодії зі страхом смерті);

- відновлення психологічного здоров'я особистості, що зазнала психотравми;

- інформаційна поведінка дітей і дорослих в умовах глобалізації і гібридної війни;

- питання медіатравми, кіберсоціалізації та кібербулінгу тощо.

При цьому всі розроблені теорії, моделі та концепції містять технологічну складову (як правило, інноваційну), пропонують конкретний методичний інструментарій діяльності в означених напрямах і сферах.
По-третє, внесок Інституту в супроводження трансформаційних процесів полягає в безпосередній практичній участі у цих процесах, у донесенні отриманих даних і наукових розробок до споживача, якому вони адресуються.

Це й подання до органів державної влади інформаційно-аналітичних матеріалів, що готуються переважно за даними масових опитувань. Лише за останні п'ять років до Адміністрації, а тепер - Офісу Президента України, Верховної Ради України, Міністерства освіти і науки України та інших органів влади подано 30 таких матеріалів загальним обсягом 29,6 друк. арк. А від початку 2000-х років Інститут подав органам державної влади близько 300 інформаційно-аналітичних матеріалів.

Це й методична допомога центральним органам державної влади. Так, науковці Інституту вже майже два роки систематично проводять (з використанням інтенсивних тренінгових технологій) навчання працівників апарату Конституційного Суду України, що має на меті підвищення рівня їхньої комунікативної компетентності, оволодіння навичками ефективного ділового спілкування як усередині в апараті, так і з громадянами, котрі звертаються до суду.

Це й масштабні експерименти всеукраїнського рівня, що проводяться в галузі освіти з метою відпрацювання алгоритмів упровадження розроблених технологій. Зокрема з такого гострого питання, як формування позитивної громадської думки стосовно планованого переходу до 12-річного терміну навчання у старшій школі, переходу, який унаслідок багатьох соціально і психологічно зумовлених причин, ще не розпочавшись, наражається на значний спротив і суспільства загалом, і самих освітян. Але ми довели: цей спротив за відповідних умов піддається подоланню. Як зазначалося в доповіді, у межах експерименту з даного питання досягнуто певних позитивних результатів.

Однак, попри наявні здобутки (тут я переходжу до проблемної частини виступу), наші можливості у супроводженні трансформаційних процесів в освіті, а тим паче в суспільстві загалом, наразі обмежені. Це слід чесно визнати. Вони обмежені як недостатньою державною підтримкою розвитку психологічної науки, так і відсутністю дієвих механізмів упровадження наших розробок і рекомендацій.

На нашу думку, комплекс цих питань можна вирішити шляхом розроблення та затвердження 
Кабінетом Міністрів України Державної цільової програми розвитку психологічної науки в Україні на 2020-2025 рр. Програма має передбачати:

- з одного боку, інституційне, фінансове та матеріально-технічне забезпечення прискореного розвитку психологічних дисциплін, що мають пріоритетне значення для наукового супроводу суспільних та освітніх трансформацій;

- з другого, - належні обсяги та розподіл фінансування на прикладні психологічні дослідження і розробки через профільні органи виконавчої влади (як і пропонувалося свого часу Комітетом Верховної Ради України з питань науки і освіти), але з обов'язковим покладенням відповідальності за впровадження отриманих результатів на замовника, а не лише на виконавця.

Такі заходи покликані ліквідувати зокрема й очевидні структурні деформації в розвитку вітчизняної психологічної науки. Адже не секрет, що за роки незалежності в Україні практично зникли психологія праці, інженерна, авіаційна психологія тощо. Поки не вдарив грім, - не розпочалася російсько-українська війна, - майже не розвивалась і військова психологія.

Ще одна надзвичайної ваги проблема - підготовка психологічних кадрів. На жаль, від ї̈ вирішення фактично відлучені наукові установи НАПН України - через постійне урізування асигнувань на освітню діяльність. Але це не означає, що можемо миритися з таким становищем. Адже проблема набуває все більшої актуальності.

Унаслідок воєнних дій на сході України психологічної допомоги вже нині потребують десятки тисяч людей. А в найближчій перспективі, за прогнозами авторитетних зарубіжних фахівців, їх буде близько 5 мільйонів! При цьому за відсутності кваліфікованої психологічної допомоги тільки внаслідок їхньої тимчасової непрацездатності (не враховуючи коштів на лікування) держава втрачатиме приблизно 30 млрд грн на рік.

Але хто надаватиме цю допомогу? Українська вища школа випускає, здавалось би, немало психологів (за першою і другою спеціальністю). Однак, не випадає закривати очі на те, що з окремих закладів вищої освіти виходять, по суті, малограмотні, недоучені психологи, не готові до роботи ні у сфері психологічної науки, ні у сфері психологічної практики, що ми бачимо і в повсякденні, і щорічно на вступних іспитах до аспірантури.

Щось, зрозуміло, можна зробити, підвищуючи їхню кваліфікацію, надаючи їм відповідні методичні матеріали, що й робить Український науково- методичний центр практичної психології і соціальної роботи. Я високо ціную зусилля цього невеликого, але напрочуд продуктивного колективу. Але навряд чи лише такі допоміжні заходи здатні докорінно змінити становище за відсутності у тих же шкільних психологів належної базової освіти.

На жаль, сьогодні в Україні дедалі більше процвітає так званий психологічний фельдшеризм (за дошкульним висловом покійного В.П. Зінченка). Тому можна зрозуміти професійні організації психологів, які в соціальних мережах б'ють із цього приводу на сполох. Але в жодному разі не можна погодитися з їхніми рецептами лікування хвороби: з пропозиціями зменшити держзамовлення на підготовку психологічних кадрів. Це нагадує лікування хворого шляхом його умертвління. Бо насправді в Україні вчать психологів не лише інколи погано, а й недостатню - тим паче для воюючої країни - кількість. У цьому переконує порівняння обсягів їх підготовки у нас і в розвинутих країнах.

Візьмімо як еталон Сполучені Штати Америки. У порівнювані роки (2014-2016рр.) річний випуск психологів з дипломами бакалаврів, магістрів спеціалістів в українських вишах становив приблизно 14 осіб на 100 тис. населення. Тоді як американські університети випускали щороку на таку ж само кількість населення до 45 бакалаврів і магістрів психології, тобто у 3,2 разу більше.

Ще разючіша різниця спостерігається в обсязі підготовки за психологічними спеціальностями фахівців вищої кваліфікації: у США на 100 тис. населення науковий ступінь $\mathrm{PhD}$ щорічно здобували у 5 разів більше осіб, ніж захищали кандидатські дисертації в Україні. При цьому в Сполучених Штатах за психологічним фахом захищалося дисертацій істотно більше, ніж у галузях фізики, комп' ютерних наук та інформаційних технологій, математики і статистики, іноземних мов та лінгвістики тощо.

Слід зауважити також, що значний випуск психологів зі ступенем PhD сприяє у Сполучених Штатах передусім розвитку практичної психології, оскільки в цій сфері вони отримують найкращі шанси працевлаштування. Тоді як в Україні практична психологія, сфера психологічних послуг асоціюються зазвичай із безступеневістю, квазінауковим аматорством. Принаймні саме такими практичними психологами і консультантами заповнений переважно національний телевізійний і радійний ефір. 
До речі, дані про кількість дисертацій, які захищаються у США за різними галузями знань, становлять інтерес ще й тому, що не залишають каменя на камені від однієї з безглуздих претензій до НАПН з боку деяких членів Наукового комітету Національної ради України з питань розвитку науки і технологій. Їх обурює те, що в Україні дисертацій з педагогіки захищають набагато більше, ніж із фізики. Але ж, як бачимо, й у такій «відсталій» країні, як США, дисертацій з освітньої проблематики (аналог нашої педагогіки) теж удвічі більше, ніж у галузі фізики. Тобто маємо цілковитий абсурд: НАПН України звинувачують у тому, що Україна, виявляється, перебуває у світовому тренді захисту дисертацій з проблем освіти.

От би ще потрапити в цей тренд і психологам!

А для цього державне замовлення на підготовку психологічних кадрів потрібно не зменшувати, а збільшувати, але водночас оптимізувати його розміщення, віддаючи перевагу провідним університетам, до яких немає питань у плані якості навчання. А також повною мірою використовуючи освітні можливості наукових установ психологічного профілю, можливості фактично не задіяні.

Тому проєктом постанови загальних зборів за нашою пропозицією передбачено порушити перед МОН України питання щодо:
1) поліпшення підготовки психологів у закладах вищої освіти, посилення вимогливості до надання ліцензій на підготовку фахівців за спеціальностями «Психологія» та «Соціальна робота»;

2) поетапного збільшення обсягу державного замовлення на підготовку психологів за бакалаврськими, магістерськими та докторськими програмами, диференційованими відповідно до прогнозно визначеної потреби у психологічних кадрах для наукової і практичної роботи;

3) розміщення істотної частини державного замовлення на підготовку психологічних кадрів за докторськими і магістерськими програмами у наукових установах психологічного профілю НАПН України;

4) підготовки та підвищення кваліфікації українських психологів за кошти державного бюджету у провідних зарубіжних університетах, а також в Україні за участю зарубіжних викладачів.

Звичайно, є й інші проблеми, що стають на заваді нарощуванню нашого потенціалу сприяння трансформаційним процесам в українському суспільстві та освіті. Але всі вони так чи інакше залежать від вирішення проблеми психологічних кадрів. Тому ії слід розглядати сьогодні як пріоритетну.

\title{
OUR CONTRIBUTION TO TRANSFORMATION PROCESSES: WHAT IS IT AND WHAT IS NEEDED FOR ITS INCREASE \\ Scientific report at the General Meeting of the National Academy of Educational Sciences of Ukraine, December 17, 2019
}

Mykola Slyusarevskyy

PhD in Psychology, Corresponding Member of NAES of Ukraine, Director, Institute for Social and Political Psychology of the National Academy of Educational Sciences of Ukraine, Kyiv, Ukraine

\begin{abstract}
The main directions of Ukrainian social psychologists' support for transformation processes in society and education are characterized: 1) monitoring the tendencies of the dynamics of social consciousness with the help of allUkrainian representative polls; 2) development of practically oriented theories, models and concepts that form the theoretical and methodological foundation of both study and support of social changes; 3) brining the received data and scientific developments to the consumer, scientific and methodological assistance to the state authorities. At the same time, it was stated that the possibilities of psychological support of transformational processes in education, and especially in the society as a whole, are currently limited both by insufficient state support for the development of psychological science and by the lack of effective mechanisms for implementation of existing developments and recommendations. The necessity to approve at the governmental level the State target program for the development of psychological science in Ukraine is substantiated. The problem of training of psychological personnel is extremely acute for the country, which is actually in a state of war. For its actualization a comparative analysis of the state of training of psychologists in Ukraine and the USA was conducted. The conclusion was made about the need for increasing the volume and at the same time more rational realization of the state order for training of domestic psychological personnel, which envisages its placement in leading universities and scientific institutions of psychological profile.

Keywords: society; education; psychological support; State program of psychological science development; psychological personnel; state order for training of psychologists.
\end{abstract}

